\title{
The Turn of Marx and Engels' View of Historical Materialism
}

\author{
Pengcheng Li \\ Nanjing University of Aeronautics and Astronautics \\ Nanjing, China \\ Jiangsu Normal University \\ Xuzhou, China
}

\author{
Yanling Mei \\ Jiangsu Normal University \\ Xuzhou, China
}

\begin{abstract}
Marx and Engels were not born natural historical materialists. His historical materialism thought was based on the criticism of Hegelian idealism and Feuerbach's humanistic materialism. For the first time, the concept of historical materialism was elucidated in "German Ideology", and the basic principles of historical materialism were systematically and exhaustively discussed, thus achieving a great transformation in the history of philosophy. This paper selects Marx and Engels's criticism of Feuerbach's humanism to expound Marx and Engels's transcendence of Feuerbach and the birth of historical materialism, thus deepening the understanding of this issue.
\end{abstract}

Keywords-historical materialism; Marx and Engels; "German Ideology"; Feuerbach

\section{INTRODUCTION}

Engels pointed out that historical materialism is "the science of people and their historical development". Marx and Engels were the founders of this science and struggled for the spread and application of this science. However, they are not born natural historical materialists. Just like what we usually call "Marx is not a born Marxist," their philosophical thinking has undergone three stages of development, namely, the idealism of the young Hegelians, Materialism Feuerbach, dialectical materialism, and historical materialism.

Both Marx and Engels' philosophical thoughts originated from Hegel's philosophy. They were initially the believers of Hegelian philosophy. Both the historical outlook and the natural outlook were idealism and belonged to the young Hegelians. In 1841 Feuerbach's The Essence of Christianity was published, restoring the authority of materialism. They were influenced by Feuerbach's humanistic philosophy and turned from idealism to materialism and belief in Feuerbach's humanistic philosophy, becoming the Feuerbach. Later, in the process of participating in practical work, Marx and Engels witnessed the importance of real interest struggles and began to embark on the path of historical materialism. From the spring of 1845, Marx started to liquidate his belief in Feuerbach's philosophy and criticized Feuerbach's humanism. The "German Ideology" was created by Marx and Engels in order to settle the previous philosophical beliefs, which was written on the position of historical materialism.

\section{Those Who Criticize FeuerbaCh'S AbStRaCtion, WHO DETERMINE THE REALITY IS THE PREMISE OF HUMAN HISTORY}

Feuerbach's core philosophy is "worship of abstract people," he does not put people "as human action in history to study," so that he "cannot find the road toward the living real world from the abstract kingdom he extreme hate." Therefore, in the view of history, he cannot get rid of the "traditional idealist bondage". [1] Marx and Engels realized through their own practical activities and theoretical studies that they must "transition from the abstract people of Feuerbach to the real, living ones, "must treat these people as people who are acting in history", "make the science of society, the sum of the socalled history science and philosophical science, coordinate with the foundation of materialism, and transformed on this basis." Therefore, they decided to liquidate their belief in Feuerbach, criticize Feuerbach's humanism, formulate historical materialism, and expound the basic principles of historical materialism. This work began in the spring of 1845 .

Marx began in July 1841 and Engels began in the second half of 1841, they two studied Feuerbach's book "The Essence of Christianity". They accepted Feuerbach's materialist view of nature and summarized it "'there is nothing outside of nature and human beings, the supreme being created by our religious illusions is only an illusory reflection of our inherent nature". "The material, perceivable world to which we belong is the only reality; and our consciousness and thoughts, no matter how super-feeling it may seem, are always the physical, physical organs that are the products of the human brain. The material is not the product of the spirit, but the spirit is only the highest product of the material." Because they were influenced by the philosophy of Feuerbach, they turned from idealism to materialism and became Feuerbach. Engels said: "In our turmoil, Feuerbach gave us more influence than any other philosopher after Hegel," when talked about Feuerbach's influence on them. "At that time, everyone was very excited about having become Feuerbach for a while."[2]Until 1844, they did not completely get rid of Feuerbach's influence, not only in their writings, but also in their overestimate of Feuerbach. Marx said in his "Economic and Philosophical Manuscripts of 1844": "In addition to these writer who critically studied national economics, the general empirical criticism, and thus the Germans' critique of the empirical 
evidence of national economics, is based on Feuerbach. Kazakhstan's discovery lays a solid foundation for it." "The empirical criticism of humanism and naturalism began with Feuerbach ... His writing is the only work contains of a true pathological revolution after Hegel's "Phenomenology" and "Logic".[3] Marx and Engels wrote in the co-authored "The Holy Family": "Only Feuerbach is finished and criticized Hegel's philosophy from Hegel's point." Feuerbach attributed the absolute spirit of metaphysics to 'nature-based real people', thus completing a critique of religion, and cleverly drafting the basic point of Hegel's speculation and all metaphysical criticism." These evaluations are obviously too high." In the spring of 1845 , they began to feel that it was necessary to liquidate their previous philosophical beliefs and criticize Feuerbach's humanistic philosophy. Therefore, they decided in Brussels to delve into their "intelligence" and liquidate "former philosophical beliefs", formulation historical materialism, expounds their ideas and their "contradictions with the views of the German philosophical ideology." In this way, they must not only criticize Hegel and the young Hegelians but also criticize Feuerbach. The critique of Hegel and the young Hegelians was achieved through Marx's "Critique of Hegelian Philosophy" in 1843 and "The Holy Family" co-authored by Marx and Engels from 1844 to 1845. The criticism of Feuerbach began in the spring of 1845. First of all, Marx wrote "The Outline of Feuerbach" (Spring of 1845), preparing for systematic criticism of Feuerbach. Then Marx and Engels coauthored the "German Ideology" (1845 - 1846) and thoroughly settled Hegel's philosophy, including Feuerbach. Especially through the criticism of Feuerbach's humanistic philosophy, they embarked on historical materialism and systematically expounded the basic principles of historical materialism.

In "German Ideology", Marx and Engels first criticized Feuerbach's abstract people and determined that the premise of human history is real people. They pointed out: "Feuerbach never sees real, active people, but stays on the abstract 'human' and confined to the recognition of 'realistic, individual, physical persons within the scope of their feelings.' In other words, in addition to love and friendship, only the idealized love and friendship, he does not know what other 'human relationships' exist between 'people."' "The world in which this person lives is not mentioned at all, so this person is always the kind of abstract person that is said in the philosophy of religion. This person is not born from his mother's womb. He is born from the god of monotheism. So he is not living in a real, historically and historically determined world; although he interacts with other people, any other person is as abstract as himself."Marx and Engels criticized Feuerbach's humanist idealism with this abstract person as the core, replacing the Feuerbach's abstract people with real, living people, "taking these people as ones act in history to study." As a result of this, they realized that the premise of human history is real people, not abstract people. They said: "the first prerequisite for the history of any human being is undoubtedly the existence of an individual with life." The premise of history is man, but not some kind of person who lives in an imaginary alien settlement and fixed state, but persons in the course of development under realistic conditions that can be observed through experience." Therefore, they determined the premise of human history as a real person.

\section{PeOPle Who Criticize FeUerbach's Pure NAtURe, DETERMINE THAT MATERIAL PRODUCTION IS THE SOURCE OF HUMAN HISTORY}

Proceeded from the real people, Marx and Engels criticized Feuerbach's pure nature, carefully studied people's practical activities and the society in which they lived, and discovered that the source of human history was material production.

Feuerbach's humanistic philosophy is materialistic in view of nature, because it emphasizes that nature and people are the only realities. When criticizing religion, he denies the personality of God and denies that God is the spiritual entity, emphasizes that people create God, rather than that God Creates people. However, from a historical point of view, it is still idealist. Because he does not understand the society in which people live, nor does he understand the social roots of religion. On the contrary, he regards the historical changes in religion as "the reason human beings distinguish each other at different times." He understands human nature as "Class" that is "an inner, silent, commonality linking many people to pure naturalness" and does not see "it is the sum of all social relations". Therefore, Feuerbach fell into idealism in the historical field. The basic reason is that he does not start from the real person, but starts from abstract people and treats people as pure natural people, and he discusses history on these. As Marx and Engels pointed out, "When Feuerbach is a materialist, history is outside his horizons. When he goes to explore history, he is never a materialist."

Marx and Engels critiqued Feuerbach's pure nature, studied man as a person active in society, and discovered the initiative of man's practical activities, thus establishing that material production is the source of human history. They pointed out that Feuerbach "he sees people only as 'perceptual objects' rather than 'perceptual activities' because he is observe people in the field of theory but not from people's existing society contact, not from the surrounding living conditions that make people like this", "He did not criticize the current relationship of life, and thus never understood the perceptual world as the common, living, individual of the world that constitutes it. "He only understood things, reality, and sensibility in the form of objects or intuition, but not as sensible activities for human beings and understanding of practice". The reason for Feuerbach's understanding of human beings is that he only unilaterally emphasizes that people are the product of nature, and regards the natural attributes of human beings as the only attribute. Therefore, he only seeks differences from one aspect of human nature between people and animals, therefore, he cannot really understand the fundamental difference between humans and animals is that people can engage in material production and labor, and can create material conditions for their own survival. People are not simply relying on nature, but more importantly, they actively transform nature and humanize nature to serve humanity. Therefore, he also necessarily does not understand that man and nature, the basis of subjective and objective unity, is an active human activity.

In contrast to Feuerbach, Marx and Engels not only introduced practice into epistemology, but more importantly introduced the concept of history. From the view of practice, they examined all social phenomena. They discovered that: 
"The first prerequisite for any human history is undoubtedly the existence of an individual with life. Therefore the first fact that needs to be determined is the physical organization of these individuals and the relationship between them and the natural world that is restricted by the physical organization." "Any historical record should start from these natural foundations and their changes in people's activities in the course of history." The "natural basis" here is in terms of production methods. This kind of production method is formed by people in practical activities. Therefore, "this mode of production should not only be examined from the perspective of the reproduction of the individual's physical existence. It is to a greater extent the mode of activity of these individuals, expressing certain forms of their lives, their certain ways of life. How individuals express their own lives, and what they themselves are. Therefore, what kind of people they are, this is consistent with their production - that is, what they produce, but also consistent with how they product. Therefore, what kind of individual depends on the physical conditions of their production." "So the first thing in any view of history is to pay due attention to the full meaning and scope of the above basic facts." Therefore, Marx and Engels, under the condition of acknowledging that nature is first, are more emphasizing the material conditions created by people through their own practical activities. They said: "In order to be able to 'create history', people must be able to live. However, in order to live, they first need to address food and clothing and other things. Therefore, the first historical activity is to produce materials that meet these needs, namely, produce material life itself." And pointed out that this is "the first prerequisite for the survival of all human beings is the first prerequisite for all history." It is precisely because of this that Marx and Engels identified material production as the source of human history. Based on this, Marx and Engels systematically expounded the basic principles of historical materialism.

\section{DisCUSSING THE BASIC PRINCIPLES OF HISTORICAL MATERIALISM FROM THE PERSPECTIVE OF REAL PEOPLE AND MATERIAL PRODUCTION}

In "German Ideology", Marx and Engels determined that the premise of human history is the real person through the critique of Feuerbach's abstract people and pure nature. The source of human history is material production. As a starting point, they studied and explored the history of mankind, revealed the basic laws of the development of human history, formulated the historical materialism, and expounded the basic principles of historical materialism. They said that our "concept of history lies on explaining the actual production process from the production of direct living substances, and associating with this kind of production method, the communicative forms it generates, that is, the civil society at various stages, are understood as the basis of the entire history, describes the civil society from the civil society as the national activity, and at the same time elucidates the products and forms of all the various theories of consciousness, such as religion, philosophy, morality, etc., from the civil society, and traces the process of their production". Following this path, Marx and Engels first expound the decisive role of material production in social life. They point out that human history is premised on the existence of a living individual. However, the existence and existence of a living individual can be sustained is always based on meeting the material production and selfproduction that people need to survive. Without these two kinds of production, there will be no human history. In these two kinds of production, there are three "aspects" or three "factors", namely the production of the living materials, the production of the means of production, and the people's own production (reproduction). They think: "From the earliest days of history, when the first group of people appeared, the three existed at the same time, and it is still playing a role in history." However, what they emphasize more is the production of material information that plays a decisive role in this, namely, the production of living materials and means of production. Therefore, they regard material production as "the first prerequisite for the survival of all humankind", "the first historical activity" and "a basic condition for all history."

Marx and Engels then analyzed the mode of production. In the analysis, they pay special attention to the decisive role of productivity. They pointed out: "The total amount of productivity people have achieved determines social conditions." With the development of productivity, there must be contradictions between the productivity and the relations of production. When such contradictions cannot be resolved within the existing production methods, productivity requires new production relations to be compatible with them. Therefore, in the history of mankind, with the continuous development of productivity, the series "constitutes a connected form of communication", "the connection of the forms of communication lies in: the old form of communication that has become obedient is adapted to the more advanced productivity, therefore, is replaced by a new form of communication that adapts to the more progressive type of personal autonomy; the new forms of communication become ambiguous and are replaced by other forms of communication." Based on this historical fact, Marx and Engels have elucidated various forms of ownership and their successive replacements, thus revealing the dynamics and prospects of transitioning or transforming from one social form to another higher social form.

In "German Ideology", Marx and Engels first discussed the dialectical relationship between productivity and production relations, and pointed out that the contradiction between productive forces and production relations is the fundamental driving force for the development of social history. They said: "According to our point of view, all historical conflicts are rooted in the contradiction between productive forces and forms of communication." "This contradiction between productive forces and forms of association (as we have seen, it has happened many times in the past history, but it has not threatened the foundation of this form). Each time it must inevitably burst into a revolution. At the same time, it also adopts various incidental forms - manifested as the sum of conflicts, manifested as conflicts between various classes, conscious contradictions, ideological struggles, political struggles, etc."[4]Here, they use "communicative form" to express the meaning of the production relationship. As far as the terminology is concerned, it is not quite clear. However, from the content, the meaning of the production relationship has been clarified and the contradiction movement between the 
productivity and the production relationship is the root cause of the revolution that has been discussed. Therefore, in fact, it reveals the dialectical relationship between productivity and production and the fundamental driving force for the development of social history.

In "German Ideology", Marx and Engels also discussed the dialectical relationship between economic fundamentals and superstructure. They pointed out that the economic basis is "the foundation of the entire history, and then must describe the activities of the economic base within the scope of national life, and proceed from the economic basis," "to clarify various theoretical products and forms of consciousness, such as religion, philosophy and morality, etc. and trace the process of their production on this basis." "This view of history is different from history idealism. It does not seek a certain category in each era, but it always stands on the basis of real history. It does not interpret practice from the point of view, but interpret conceptual things starts from material practice, one can also draw the following conclusion: All forms and products of consciousness cannot be destroyed by spiritual criticism, nor can they be melted into 'self-consciousness' or turned into 'phantom', 'strange shadows', 'strange', etc. and be eliminated. It is only by actually overturning the social relations of reality that this idealistic paradox has created that can destroy them; the motive force of history and the driving force of religion, philosophy, and any other theories are revolutionary rather than critical." Marx and Engels discovered the dialectical relationship between economic fundamentals and superstructure by studying the relationship between social structure, political structure and production, and expounded a series of basic principles concerning economic fundamentals and superstructure. They said: "Our starting point is to engage in practical activities, and we can also reveal the reflection of ideology and the development of echo from the process of their real life. Even the things that are ambiguous in people's minds are also the inevitable sublimation of their material life processes that can be determined through experience and linked to material preconditions. Therefore, morality, religion, metaphysics, and other ideologies, as well as the forms of consciousness that are compatible with them, lose the appearance of independence... Those who have developed their own material production and material exchanges have changed their reality and at the same time have changed the products of their own thinking and thinking. It is not consciousness that determines life, but life that determines consciousness. "[5]

\section{CONCLUSION}

Marx and Engels were not born natural historical materialists. The formation of historical materialism was that determined that "real people" is human history based on the judgment of Feuerbach's "abstract people", determined that "material production" is the source of human history on the basis of Feuerbach's pure "natural person"; then proceed from the "realistic man and material production" to discuss the basic principles of historical materialism, and to achieve transcendence over Feuerbach's related theories. This achieved great changes in the history of philosophy, deepened the understanding of this issue, and completed the change of historical materialism.

\section{REFERENCES}

[1] "Selected Works of Marx and Engels", Volume 4, People's Publishing House, 1972 Edition, p. 237, 236, 227. 《马克思恩格斯选集》第 4 卷，人民出版社 1972 年版，第 237、236、227 页。

[2] "Selected Works of Marx and Engels", Volume 4, People's Publishing House, 1972 Edition, p. 208, 218. 《马克思恩格斯选集》第 4 卷, 人 民出版社 1972 年版，第 208、218 页。

[3] Marx: "Manuscript of Economic and Philosophical Manuscripts of 1844", Translated by Liu Pikun, People's Publishing House, 1979 Edition, p. 2 and 3. 马克思: 《1844 年经济学哲学手稿》, 刘丕坤 译，人民出版社，1979 年版，第 2、3 页。

[4] "Complete Works of Marx and Engels", Volume 3, People's Publishing House, 1960 Edition, p. 83-84. 《马克思恩格斯全集》第 3 卷，人民 出版社 1960 年版, 第 83-84 页。

[5] "Complete Works of Marx and Engels", Volume 3, People's Publishing House, 1960 Edition, p. 30. 《马克思恩格斯全集》第 3 卷, 人民出版 社 1960 年版, 第 30 页。 